\title{
Double Isotope Dilution Derivative Assay of Digitoxin in Plasma, Urine, and Stool of Patients Maintained on the Drug *
}

\author{
Daniel S. Lukas † and Ralph E. Peterson \\ (From the Department of Medicine, Cornell University Medical College, New York, N. Y.)
}

Although the cardiac glycosides have been used extensively since Withering published his observations on the effects of foxglove nearly two hundred years ago (1), their distribution and metabolism and the cellular basis of their action in man are unknown. The lack of sufficiently sensitive, chemically specific methods of assay has hampered studies of the biologic behavior of these compounds.

The sensitivity of available spectrophotometric and fluorometric methods is limited to $2 \mu \mathrm{g}$ or more, and none of them are molecularly specific, since they involve structural components common to all cardenolides and many glycosides. Thus, production of color depends on the action of various reagents on either the lactone ring $(2-11)$ or the 2-deoxy sugar residues (12-20). The $\alpha, \beta$ unsaturated lactone ring is also responsible for absorption of ultraviolet light at a wavelength of $217 \mathrm{~m} \mu$ (21). Fluorescence results from the action of strong acids on the steroid segment of the molecule and is attributable to dehydration and oxidation products and the formation of accessory ring structures (22-27). All these reactions are subject to interference by numerous substances.

Most current information regarding the metabolism of the cardiac glycosides is derived from studies employing bioassay methods $(28-41)$ or the administration of radioisotopically labeled compounds (42-53). Bioassay with the chick or duck

* Submitted for publication October 19, 1965 ; accepted February 4, 1966.

Supported by grants HE 08950-01, AM 04855, and FR 47 from the U. S. Public Health Service, National Institutes of Health.

Presented in part at the 56th Annual Meeting of the American Society for Clinical Investigation, Atlantic City, N. J., May 4, 1964 (J. clin. Invest. 1964, 43, 1242). † Address requests for reprints to Dr. Daniel S. Lukas, The New York Hospital-Cornell Medical Center, 525 East 68th Street, New York, N. Y. 10021. embryo heart is sensitive to 0.005 to $2 \mu \mathrm{g}$ of cardenolide or glycoside, depending on the source of the biologic extract and the degree of purification $(28-32,41)$, and even smaller quantities of glycoside labeled with ${ }^{14}$ carbon (48-50) or tritium (5153) can be detected. Neither method, however, is intrinsically specific.

Bioassay measures not only the parent compound but also its active metabolites, as well as other cardioactive substances in the sample. Similarly, radioactivity in samples from a subject given a radioisotopically labeled glycoside may represent the original compound, metabolites, or degradation products commonly formed during extraction of submicrogram quantities of steroids. Isolation of the glycoside from its metabolic products by partition with solvents (43) and by paper (39) or column (45) chromatography before bioassay or radioassay has improved specificity, but precision is impaired unless means are incorporated to correct for losses during these procedures. An additional disadvantage of the direct administration of radioisotopic compounds to human subjects is that it can be used only for acute studies.

The double isotope dilution derivative method is one of the most sensitive, precise, and chemically specific methods for measuring steroids in biologic extracts (54-57). As little as $0.2 \mathrm{~m} \mu \mathrm{g}$ of aldosterone in peripheral plasma can be determined (56). The method has proved to be applicable to digitoxin. This paper describes the techniques employed and presents data on digitoxin in the plasma, urine, and stool of patients treated chronically with this glycoside.

\section{Methods}

Principle of assay. A quantity of tritium-labeled digitoxin of high specific activity was added to the sample at the beginning of the analysis. Digitoxin was extracted from the sample and converted to digitoxin triacetate $-1{ }^{14} \mathrm{C}$, which was isolated and purified. The amount of "carbon 
in the pure derivative is related stoichiometrically to digitoxin content. The ratio of tritium added initially to the amount recovered was used to correct for loss of digitoxin during analysis.

Preparation of digitoxin- ${ }^{3} \mathrm{H}$. Five to $10 \mathrm{mg}$ of digitoxin 1 was subjected to exchange with tritium gas ${ }^{2}$ (58). Digitoxin- ${ }^{8} \mathrm{H}$ was separated from radiation byproducts by partition between dichloromethane ${ }^{3}$ and water and by descending chromatography of the residue from the dichloromethane layer on $18-\times 55-\mathrm{cm}$ sheets of Whatman no. 1 paper at $26^{\circ} \mathrm{C}$ for 8 hours in a solvent system containing benzene, methanol, and water in a volumetric ratio of $4: 2: 1$. Twenty $\mu \mathrm{g}$ of authentic digitoxin was chromatographed on a separate region of each paper. One to two thin strips were cut in the direction of development from each paper and dipped into a freshly prepared mixture of 3 vol $1 \% m$-dinitrobenzene 4 and 1 vol $40 \%$ benzyltrimethylammonium hydroxide in methanol. Digitoxin was identified by the blue color it developed and by its position relative to the nonradioactive standard. The corresponding peaks of radioactivity on the remaining sheets of paper were located with a strip scanner. ${ }^{5}$ Digitoxin- ${ }^{8} \mathrm{H}$ was eluted from these segments of paper with methanol and submitted to four additional chromatographies in the following solvent systems: cyclohexane, dioxane, methanol, water $(4: 4: 2: 1$, vol/vol) for 3 days; and cyclohexane, dioxane, methanol, water $(4: 3: 2: 1)$ for 4 days.

Methanol in the eluate from the final chromatogram was evaporated in a water bath at $37^{\circ} \mathrm{C}$ with an air jet. The residue was dissolved in $40 \mathrm{ml}$ of dichloromethane and shaken with 2 to $3 \mathrm{ml}$ of water. After aspiration of the water layer containing fragments of filter paper, the dichloromethane was evaporated. Ethanol was added to the digitoxin- ${ }^{8} \mathrm{H}$ to make a stock solution, which was stored at $-20^{\circ} \mathrm{C}$.

Purity of the digitoxin- ${ }^{8} \mathrm{H}$ and chemical identity with authentic digitoxin were established by three serial recrystallizations of a mixture of $150 \mathrm{mg}$ digitoxin and $10.3 \mu \mathrm{c}$ of digitoxin- ${ }^{8} \mathrm{H}$ from $1: 2$ ( $\mathrm{vol} / \mathrm{vol}$ ) ethanolpetroleum ether. A portion of the initial mixture and the crystals and mother liquor from each recrystallization were dried. A quantity of each was weighed and dissolved in ethanol. These solutions were assayed for tritium activity with a liquid scintillation spectrometer ${ }^{6}$

1 We are indebted to Dr. James A. Dingwall of the Squibb Institute for Medical Research, New Brunswick, N. J., for generous supplies of pure $(99.6 \%)$ digitoxin.

2 New England Nuclear Corp., Boston, Mass.

${ }^{8}$ All dichloromethane used in this study was purified by passage through a $7-\times 40-\mathrm{cm}$ column of $28-$ to 200 -mesh silica gel.

4 Grade V, Sigma Chemical Co., St. Louis, Mo.

5 Automatic Chromatogram Scanner, Vanguard Instrument Corp., La Grange, Ill., or Radiochromatogram Scanner System, model 7201, Packard Instrument Co., La Grange, Ill.

6 Tri-Carb liquid scintillation spectrometer, series $314 \mathrm{E}$ or model 3003, Packard Instrument Co., La Grange, Ill.

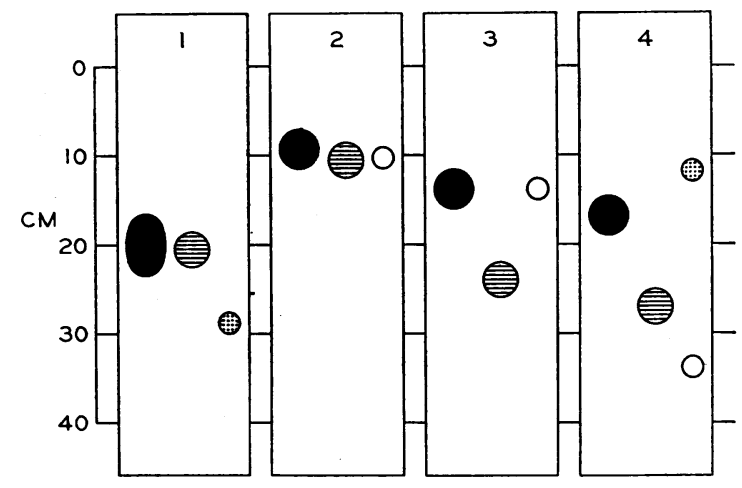

Fig. 1. Schematic Representation OF PAPER ChroMATOGRAMS SHOWING MOBILITY OF DIGITOXIN TRIACETATE AND RELATED MARKERS IN FOUR SOLVENT SYSTEMS. Digitoxin triacetate is depicted as a black spot, aldosterone diacetate as a horizontally hatched circle, rhodamine $B$ as an open circle, and F-11 as a dotted circle. Solvent system $1=$ cyclohexane, benzene, methanol, water $(100: 25$ : $100: 15)$ for 20 hours; system $2=$ cyclohexane, dioxane, methanol, water $(10: 2: 10: 1)$ for 24 hours, system $3=$ isooctane, $t$-butanol, methanol, water $(4: 2: 4: 1)$ for 62 hours, and system $4=$ mesitylene, methanol, water $(3: 2$ : 1 , reversed phase) for 20 hours.

using a toluene phosphor. ${ }^{7}$ The specific activities of all crystals and mother liquor residues deviated from the specific activity of the initial mixture by no more than $3 \%$.

In another demonstration of purity, a mixture of $3 \mathrm{mg}$ digitoxin and $1.8 \mu \mathrm{c}$ digitoxin- ${ }^{8} \mathrm{H}$ was chromatographed in cyclohexane, dioxane, methanol, and water $(4: 4: 2$ : 1) for 24 hours, rechromatographed in cyclohexane, dioxane, methanol, and water $(4: 3: 2: 1)$ for 3 days, and then converted to digitoxin- ${ }^{8} \mathrm{H}$ triacetate by treatment with acetic anhydride and pyridine. The triacetate was purified by chromatography in systems 1 and 4 (Figure 1). Digitoxin content of the initial mixture, of eluates from each of the first two chromatographies, and of the triacetate derivative was determined spectrophotometrically by a modified alkaline $m$-dinitrobenzene color reaction; tritium content was measured by liquid scintillation. The specific activity of the initial mixture remained constant within $2.8 \%$ through all of these procedures.

Still another proof of the purity of the tritiated digitoxin was provided by the correspondence of measured to anticipated ${ }^{14}$ carbon to tritium ratios in triacetate- $1-{ }^{14} \mathrm{C}$ derivatives of various combinations of digitoxin and digitoxin- ${ }^{8} \mathrm{H}$ (see below).

These procedures, which involved multiple sequential solution of digitoxin- ${ }^{8} \mathrm{H}$ in different solvents, exposure to acetic anhydride at $56^{\circ} \mathrm{C}$ for several days, and storage for a prolonged period in ethanol, also demonstrated that tritium comprised a chemically stable component of the molecule.

Specific activity of the digitoxin- ${ }^{2} \mathrm{H}$ was determined by

${ }^{7}$ Liquifluor, Pilot Chemical Co., Watertown, Mass. 
converting 0.25 to $2.5 \mu \mathrm{g}$ of the compound to the triacetate derivative with acetic anhydride- $1{ }^{14} \mathrm{C}$. After the digitoxin- ${ }^{3} \mathrm{H}$ triacetate- $1-{ }^{14} \mathrm{C}$ was purified by paper chromatography in the four solvent systems used for the double isotope dilution derivative method, its tritium and ${ }^{14}$ carbon contents were determined. The specific activity of the tritiated digitoxin was calculated from the known specific activity of the acetic anhydride. Determinations using several different lots of acetic anhydride- $1-{ }^{14} \mathrm{C}$ yielded values of $0.76 \mathrm{mc}$ per $\mathrm{mg}$ for one lot of digitoxin and $0.72 \mathrm{mc}$ per $\mathrm{mg}$ for a separately prepared lot. $\mathrm{Hy}$ drolysis of the glycoside and measurement of the specific activity of the free genin by converting it to digitoxigenin $-{ }^{3} \mathrm{H}$ acetate $-1-{ }^{14} \mathrm{C}$ demonstrated that only $33 \%$ of the tritium in the digitoxin was associated with the genin.

Specific activity of acetic anhydride- $1-{ }^{14} \mathrm{C}$ was determined by using it to acetylate cortisol and subsequently measuring the ${ }^{14}$ carbon and cortisol content of the resultant cortisol acetate- ${ }^{14} \mathrm{C}(54)$.

Alkaline m-dinitrobenzene color reaction. The following modification of existing methods (2-5) for performing this reaction was employed. The solution to be assayed was dried in a test tube. One-tenth $\mathrm{ml}$ of $1 \%$ $m$-dinitrobenzene in redistilled ethanol (54) and $0.4 \mathrm{ml}$ of $40 \%$ benzyltrimethylammonium hydroxide in methanol were mixed thoroughly with the contents of the tube. Full development of blue color was achieved in 1 minute. The color was stabilized with $3 \mathrm{ml}$ ice cold redistilled ethanol. The solution was transferred to a $19-\times 105-\mathrm{mm}$ cuvette, and its optical den $\$$ ity at $610 \mathrm{~m} \mu$ was determined in a Coleman Junior spectrophotometer at 2 minutes after addition of the organic base. Standards of 20,40 , and $60 \mu \mathrm{g}$ were similarly treated. Optical density varied linearly with concentration. The coefficient of variation for replicate determinations of 10 to 60 $\mu \mathrm{g}$ was $1 \%$. The color, which is specific for the lactone ring, has a molar absorbancy index for digitoxin of 18,400 . Since water inhibits development of color, its introduction into reagents or reaction mixture was meticulously avoided.

Acetylation of digitoxin. Treatment of digitoxin with acetic anhydride in a molar ratio of $1: 100$ and pyridine produces a mixture of four acetates of digitoxin, which can be separated and identified by paper chromatography. The four free hydroxyl groups of the digitoxose residues are the sites of acetylation. The $14 \beta$-hydroxyl group within the steroid moiety of the molecule is tertiary and relatively unreactive.

For double isotope dilution derivative assay, a mixture of acetates (mono-, di-, tri-, and tetra-) would be inconvenient because of limited yield of any single derivative. It was not possible to devise conditions for acetylation of microgram quantities of digitoxin that would consistently yield only the tetraacetate without considerable degradation of digitoxin.

Yields of digitoxin triacetate greater than $80 \%$, however, were obtained by treating digitoxin with pure acetic anhydride (molar ratio $1: 100$ ) and pyridine (1/1.5, vol/ vol) at $56^{\circ} \mathrm{C}$ for 4 days in sealed tubes. With acetic an- hydride $-1-{ }^{14} \mathrm{C}$, which because of its volatility and expense is handled as a $20 \%$ solution in anhydrous benzene, the molar ratio of acetic anhydride to digitoxin had to be increased to $300: 1$ to achieve $90 \%$ yields of digitoxin triacetate under otherwise similar conditions.

That the compound formed in this reaction is digitoxin triacetate was established in several ways. One $\mathrm{mg}$ of digitoxin was acetylated with acetic anhydride- $1-{ }^{14} \mathrm{C}$. The triacetate was freed of impurities by paper chromatography (Figure 1). In the final eluate, digitoxin was determined by the alkaline $m$-dinitrobenzene reaction, and acetate by measuring ${ }^{14}$ carbon content. The molar ratio of acetate to digitoxin was $2.95: 1$.

Mixtures of digitoxin and digitoxin- ${ }^{3} \mathrm{H}$ in varying proportions were acetylated with acetic anhydride- $1-{ }^{14} \mathrm{C}$. The ${ }^{14}$ carbon to tritium ratios in the derivatives indicated a 3:1 molar ratio of acetate to digitoxin.

Digitoxin triacetate ( $\mathrm{mol} \mathrm{wt,} \mathrm{891.08)} \mathrm{was} \mathrm{synthesized}$ and submitted to elemental analysis, which demonstrated the following: $\mathrm{C}, 63.40 \% ; \mathrm{H}, 7.75 \%$; and $\mathrm{O}, 28.85 \%$. Calculated values were $\mathrm{C}, 63.36 \% ; \mathrm{H}, 7.91 \%$; and $\mathrm{O}$, $28.73 \%$. The melting point was 121 to $122^{\circ} \mathrm{C}$.

Assay of digitoxin in plasma or urine. A quantity of digitoxin- ${ }^{3} \mathrm{H}$ in ethanol approximately equivalent to 100 ,$000 \mathrm{dpm}$ was pipetted into a glass-stoppered cylinder. An identical amount was pipetted into each of three counting vials, dried, and put aside. The measured sample of plasma or urine was added to the cylinder and mixed thoroughly with the digitoxin- ${ }^{3} \mathrm{H}$. Digitoxin was extracted by shaking the sample with 10 vol dichloromethane. The upper aqueous layer was removed by aspiration. The lipid content of the extract was reduced by shaking with $\frac{1}{10}$ vol $0.1 \mathrm{~N} \mathrm{NaOH}$. The water layer was removed, and residual alkali was neutralized by shaking the extract with $\frac{1}{10}$ vol $0.1 \mathrm{M}$ acetic acid, which was subsequently aspirated.

The extract was transferred to a beaker; a few milliliters of ethanol was added, and the dichloromethane was evaporated by air stream from a fan. The residue was dissolved in 3 to $4 \mathrm{ml}$ ethanol and transferred with two washes of dichloromethane to a $30-\mathrm{ml}$ glass-stoppered centrifuge tube. After the solvents were evaporated by air jet at $37^{\circ} \mathrm{C}$, the contents of the tube were dissolved in $0.5 \mathrm{ml}$ ethanol, and $2 \mathrm{ml}$ water was added to produce a $20 \%$ solution of ethanol. The solution was shaken with $10 \mathrm{ml}$ cyclohexane to remove remaining lipids and nonpolar substances. After the cyclohexane layer was discarded, the compounds in the ethanolic solution were extracted with $25 \mathrm{ml}$ dichloromethane, and the aqueous layer was removed. Thirty $\mu \mathrm{g} \Delta^{\mathbf{1}}$-cortisone was added to the extract, and the dichloromethane was evaporated.

The residue was applied with a mixture of methanol and dichloromethane to Whatman no. 1 filter paper along a thin line $2 \mathrm{~cm}$ long and chromatographed in the cyclohexane, dioxane, methanol, water $(4: 4: 2: 1)$ system for 24 hours. After the chromatogram was developed, $\Delta^{1}$ cortisone was identified by its absorption of ultraviolet light at a wavelength of $254 \mathrm{~m} \mu$. Digitoxin was located by its mobility relative to the marker, and by the peak of radioactivity in scans of the chromatogram. In this 
system, digitoxin migrates $16 \mathrm{~cm}$ and $\Delta^{1}$-cortisone, $20 \mathrm{~cm}$, in 24 hours.

The section of paper containing digitoxin was cut out, and the steroid eluted in a test tube with methanol, which subsequently was evaporated. The residue was transferred with dichloromethane to a 3-ml glass-stoppered centrifuge tube. The dichloromethane was evaporated, and the residue dried in a vacuum oven at $37^{\circ} \mathrm{C}$ for a half-hour.

Acetic anhydride- $1-{ }^{14} \mathrm{C}, 0.02 \mathrm{ml}(20 \% \mathrm{vol} / \mathrm{vol}$ in benzene) ${ }^{2}$ with a specific activity of $10 \mathrm{mc}$ per mmole and $0.03 \mathrm{ml}$ of anhydrous pyridine ${ }^{8}$ were added to the tube. To insure a tight seal, the stopper was sprayed with Fluoroglide, ${ }^{9}$ inserted while still moist, and held in place by a ball-socket clamp. After the tube was rotated to dissolve all the residue, it was maintained at $56^{\circ} \mathrm{C}$ for 4 days.

The acetylation was terminated with $0.5 \mathrm{ml} 50 \%$ ethanol. To eliminate some nonpolar ${ }^{14} \mathrm{C}$-labeled compounds, the ethanol was shaken with $2 \mathrm{ml}$ isooctane, which was discarded. Digitoxin triacetate was extracted from the ethanol solution with $3 \mathrm{ml}$ carbon tetrachloride. The aqueous layer was aspirated, and the carbon tetrachloride was washed with $0.5 \mathrm{ml}$ water. After $30 \mu \mathrm{g}$ aldosterone diacetate was added, the carbon tetrachloride was evaporated.

The residue was chromatographed on paper in solvent system 1 (Figure 1). Digitoxin triacetate- ${ }^{14} \mathrm{C}$ was identified, and to separate it from other ${ }^{14} \mathrm{C}$-labeled compounds, it was chromatographed on paper in the three additional solvent systems detailed in Figure 1. Digitoxin triacetate was located in each chromatogram by radioscan and by its position relative to aldosterone diacetate and dye markers (Figure 1). Standard digitoxin triacetate ${ }^{14} \mathrm{C}$ chromatographed in parallel with the sample served as a check on this relationship and assisted in defining the dimensions of the spot to be eluted.

The triacetate was eluted from the last chromatogram in a glass counting vial. The methanol was evaporated, and $5 \mathrm{ml}$ phosphor solution was added. Tritium and ${ }^{14}$ carbon contents of the vial were measured simultaneously by liquid scintillation spectrometry. At this time, tritium content of the vials into which digitoxin $-{ }^{8} \mathrm{H}$ had been pipetted at the outset of the analysis also was measured. The average recovery of digitoxin $-{ }^{8} \mathrm{H}$ in the analysis of plasma samples was $12 \%$, with a range of 1 to $39 \%$.

In the model 3003 spectrometer, the photomultiplier tube was operated at a voltage tap of 4.80 . Tritium was determined in one channel at $40 \%$ efficiency (discriminator, 50 to 700 divisions; gain, $45 \%$ ). The efficiency for measuring ${ }^{14}$ carbon in another channel was $62 \%$ (discriminator, 150 to 700 divisions; gain, $7.5 \%$ ). The ratio of first channel to second channel counts per minute

8 The pyridine was refluxed over barium oxide for 4 to 6 hours and distilled through a fractionating column. The middle fraction boiling at $115^{\circ} \mathrm{C}$ was collected and stored over $\mathrm{CaCl}_{2}$ in a vacuum dessicator.

${ }^{9}$ Chemplast, Inc., East Newark, N. J. was 230 for tritium and 0.3 for ${ }^{14}$ carbon. Background was $12 \mathrm{cpm}$ in the first channel and 8 in the second. The ${ }^{14}$ carbon to tritium ratio in the samples was 0.05 to 1.5, which is within the range affording maximal accuracy in measuring both isotopes (59).

Digitoxin content of the sample was calculated from the following equation: micrograms digitoxin $=T_{1}[(C /$ $\left.\mathrm{T})_{\mathrm{v}}-(\mathrm{C} / \mathrm{T})_{\mathrm{d}}\right] \mathrm{M} / 3 \mathrm{~S}_{\mathbf{a}} \cdot 1,000$, where $\mathrm{T}_{1}=$ counts per minute digitoxin- ${ }^{3} \mathrm{H}$ initially added to sample; $(\mathrm{C} / \mathrm{T})_{\mathrm{V}}=$ ratio of ${ }^{14} \mathrm{C}$ to ${ }^{3} \mathrm{H}$ counts per minute in counting vial; $(\mathrm{C} / \mathrm{T})_{\mathrm{d}}=$ ratio of ${ }^{14} \mathrm{C}$ to ${ }^{8} \mathrm{H}$ counts per minute for triacetate- ${ }^{14} \mathrm{C}$ of added digitoxin $-{ }^{3} \mathrm{H} ; \mathrm{S}_{\mathrm{n}}=$ specific activity of acetic anhydride- $1-^{14} \mathrm{C}$ in counts per minute per millimicromole acetate; and $\mathrm{M}=$ molecular weight of digitoxin.

Assay of stool. Stools homogenized with water were analyzed by the method used for plasma and urine with certain modifications. The dichloromethane extract of homogenate was subjected to two successive washings with $0.1 \mathrm{~N} \mathrm{NaOH}$, followed by two washings with $0.1 \mathrm{M}$ acetic acid. The dried extract was partitioned between $3 \mathrm{ml}$ of $25 \%$ ethanol and $10 \mathrm{ml}$ of cyclohexane; the cyclohexane layer was replaced once or twice until it lacked color. The dichloromethane used to extract digitoxin from the aqueous ethanol was washed two to three times with $2 \mathrm{ml}$ water until the water was clear. After the residue in the dichloromethane was chromatographed in the cyclohexane, dioxane, methanol, water $(4: 4: 2: 1)$ system, digitoxin was eluted and chromatographed again in the benzene, methanol, water $(4: 2: 1)$ system before acetylation.

Assay of whole blood. The blood sample was diluted with an equal volume of water to hemolyze the red cells and analyzed by the method used for plasma, with one modification. The initial dichloromethane extract was washed twice with $0.1 \mathrm{~N} \mathrm{NaOH}$ and twice with $0.1 \mathrm{M}$ acetic acid.

Specificity, precision, and accuracy of method. Complete separation of digitoxin triacetate-1 $-{ }^{14} \mathrm{C}$ from other contaminating ${ }^{14} \mathrm{C}$-labeled compounds is essential for specificity of the method. Several observations indicate that this was accomplished by the procedures employed.

In determinations of the specific activity of tritiated digitoxin, the ${ }^{14} \mathrm{C}$ to ${ }^{8} \mathrm{H}$ ratio usually attained its lowest value within three chromatographies after acetylation and always after the fourth chromatography. No additional change in the ratio occurred when the compound was recovered from phosphor solution and was either rechromatographed on paper or reacetylated with nonradioactive acetic anhydride and then chromatographed as the resultant tetraacetate.

A mixture of digitoxin and digitoxin- ${ }^{3} \mathrm{H}$ was acetylated with acetic anhydride- $1-{ }^{14} \mathrm{C}$ and then chromatographed in six different solvent systems. Eluates of the triacetate after the third to sixth chromatographies showed the following ${ }^{14} \mathrm{C}$ to ${ }^{8} \mathrm{H}$ ratios : $0.067,0.069,0.068$, and 0.068 . Similarly, an additional chromatography after the routine four did not alter the ${ }^{14} \mathrm{C}$ to ${ }^{8} \mathrm{H}$ ratio of digitoxin triacetate formed during analysis of plasma, urine, or stool. 
Three 50-ml samples of plasma obtained from normal subjects not taking digitoxin were assayed. Values of digitoxin equivalent in these "blank" samples were 0.0042 , 0.0045 , and $0.0047 \mu \mathrm{g}$. The value for $100 \mathrm{ml}$ urine from a normal subject not taking the drug was $0.0002 \mu \mathrm{g}$. The blank value for $50 \mathrm{ml}$ of whole blood was $0.0008 \mu \mathrm{g}$. Blank values for three stool samples were $0.01,0.01$, and $0.05 \mu \mathrm{g}$ per $100 \mathrm{~g}$.

Mixtures of $0.03 \mathrm{ml}$ acetic anhydride- $1-{ }^{14} \mathrm{C}$ (SA, 10 mc per mmole) and $0.04 \mathrm{ml}$ pyridine were incubated, extracted, and chromatographed as in the case of digitoxincontaining samples. After each chromatography, the area of paper corresponding to the position of digitoxin triacetate was eluted. After the fourth chromatography, the eluate of this segment of paper contained only 0 to $2 \mathrm{cpm}$ of ${ }^{14} \mathrm{C}$.

Separation of digitoxin from digoxin, digoxigenin didigitoxoside, digoxigenin monodigitoxoside, digoxigenin, digitoxigenin di-digitoxoside, digitoxigenin monodigitoxoside, and digitoxigenin, compounds that have been proposed to result from the metabolic degradation of digitoxin in man $(41,42,60-64)$, was accomplished by preacetylation chromatography. Thus, in the cyclohexane, dioxane, methanol, water $(4: 4: 2: 1)$ system, digitoxin migrated $16 \mathrm{~cm}$ from the origin in 24 hours, whereas digoxin, digoxigenin, and compounds of intermediate polarity, the di- and monodigitoxosides of digoxigenin, were arrayed between 2 and $6 \mathrm{~cm}$. Digitoxigenin migrated $42 \mathrm{~cm}$; its di- and monodigitoxosides traveled 24 and $36 \mathrm{~cm}$, respectively. In benzene, methanol, water $(4: 2: 1)$, the following distances in centimeters were traversed in 8 hours: digoxin, 2; digoxigenin, 4; digitoxin, 36; and digitoxigenin, 47. Acetylation of digitoxin followed by four chromatographies of digitoxin triacetate further ensured separation. For example, after 24 hours in the cyclohexane, benzene, methanol, water $(100: 25: 100: 15)$ system, the following mobilities in centimeters were observed: digoxin tetraacetate, 14; digoxigenin diacetate, 18; digitoxin triacetate, 21; and digitoxigenin acetate, 40.

To test the precision and accuracy of the method, 0.01 to $0.2 \mu \mathrm{g}$ digitoxin was added to 3 - to $10-\mathrm{ml}$ portions of normal plasma. Analysis of these samples yielded values for digitoxin content and concentration that were $101 \pm$ $3 \%$ (mean $\pm \mathrm{SE}$ ) of the expected values (Table I) (65). Six different lots of acetic anhydride- $1-{ }^{14} \mathrm{C}$ were used in these analyses. Although analytic accuracy for the samples containing 0.01 to $0.02 \mu \mathrm{g}$ was good, the coefficient of variation of $20 \%$ indicated limited precision (66). The method was more precise when larger amounts of digitoxin were measured. For the twelve samples containing $0.2 \mu \mathrm{g}$, the coefficient of variation was $4 \%$; accuracy was reflected by a mean value (plus or minus standard error) for these assays of $0.197 \pm$ $0.002 \mu \mathrm{g}$. All the $0.2-\mu \mathrm{g}$ samples were $10 \mathrm{ml}$ in volume and, therefore, represented a digitoxin concentration of $2 \mu \mathrm{g}$ per $100 \mathrm{ml}$. They were obtained from two separately prepared pools of plasma and analyzed with three different lots of acetic anhydride. The average recovery of digitoxin- ${ }^{8} \mathrm{H}$ in these assays was $6 \%$ (range, 2 to $9 \%$ ).
TABLE I

Results of double isotope dilution derivative assays of plasma samples containing added digitoxin

\begin{tabular}{lccccc}
\hline \hline Digitoxin added $(\mu \mathrm{g})$ & 0.01 & 0.02 & 0.04 & 0.10 & 0.20 \\
\hline & & & $\mu g$ & & \\
& 0.015 & 0.020 & 0.038 & 0.098 & 0.203 \\
& 0.009 & 0.020 & 0.033 & & 0.207 \\
0.009 & 0.026 & & & 0.196 \\
0.008 & 0.017 & & & 0.193 \\
0.012 & 0.018 & & 0.196 \\
& & 0.022 & & 0.184 \\
& & 0.025 & & 0.200 \\
& & & & 0.202 \\
& & & & 0.193 \\
& & & & 0.189 \\
& & & & 0.214 \\
& & & &
\end{tabular}

In each analytic run, $200,000 \mathrm{dpm}$ of digitoxin- ${ }^{3} \mathrm{H}$ was acetylated to determine the ratio $(\mathrm{C} / \mathrm{T})_{\mathrm{d}}$ in the above equation. For each lot of acetic anhydride, the values agreed within $2 \%$. Values for specific activity of the digitoxin- ${ }^{8} \mathrm{H}$ calculated from ratios observed with different lots of acetic anhydride also agreed within $2 \%$.

Subjects. Patients studied were 19 to 72 years old and hospitalized. They had cardiac failure or atrial fibrillation secondary to valvular, myocardial, or coronary arterial disease, and they had been taking 0.05 to $0.4 \mathrm{mg}$ digitoxin daily by mouth for periods of 10 days to 12 years. In each patient, treatment had been initiated with $1.2 \mathrm{mg}$ of the glycoside in two to three divided doses during a period of 1 to 3 days. Except for three patients with impaired renal function, all subjects were free of liver and renal disease. Also studied were patients with atrial arrhythmias and rapid ventricular rates who were treated with large amounts of the drug during short periods of time and developed toxic manifestations.

Venous blood was collected in heparinized syringes. Usually, 10 to $15 \mathrm{ml}$ plasma was analyzed, although early in the study as much as $50 \mathrm{ml}$ was used. Urine was collected without preservative for three consecutive 24-hour periods. Samples of $100 \mathrm{ml}$ from each period were analyzed. Stools excreted during these 3 consecutive days were combined, weighed, and homogenized in a blender with $\frac{1}{2}$ to 1 vol water. Two hundred $\mathrm{ml}$ homogenate was assayed. All samples were stored in a frozen state before analysis.

\section{Results}

Digitoxin in plasma. In two patients, plasma was obtained immediately before the daily dose of $0.1 \mathrm{mg}$ was ingested and at $\frac{1}{2}, 1$ to 6,12 , and 24 hours thereafter. The variations in plasma digitoxin concentration in one of the patients are depicted in Figure 2. In three other subjects, plasma digitoxin concentration was followed for 6 hours after daily doses of $0.1,0.2$, and $0.4 \mathrm{mg}$. In all 


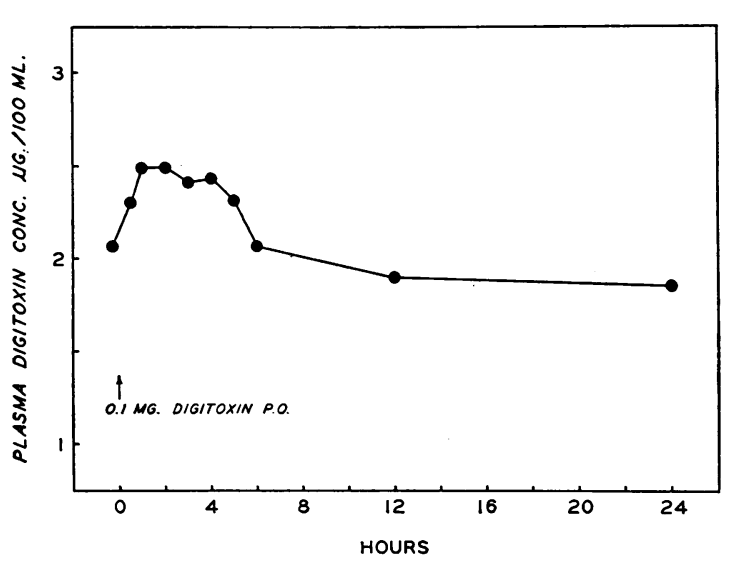

Fig. 2. Variations in PLASMa digitoxin CONCENTRATION DURING A 24-HOUR PERIOD IN A 59-YEAR-OLD WOMAN MAINTAINED ON DIGITOXIN. The daily dose of $0.1 \mathrm{mg}$ was ingested at zero time (9:00 a.m.).

subjects, increase in the concentration of the glycoside in the plasma was detected at $\frac{1}{2}$ to 1 hour after ingestion of the drug. At 1 hour, the concentration reached a peak, which was 17 to $30 \%$ greater than the initial value, and which was sustained for the ensuing 2 to 3 hours. By the fourth to sixth hour, the concentration had fallen to its initial level in all patients except one, in whom a small increment of $0.23 \mu \mathrm{g}$ per $100 \mathrm{ml}$ was still present after 6 hours.

Aside from the increase related to absorption of the daily dose of the drug, plasma digitoxin concentration remained relatively stable during the course of the day. Additional evidence of this constancy was obtained by measurements in ten other patients before and 4 to 12 hours after daily maintenance doses of 0.1 to $0.25 \mathrm{mg}$ (Figure 3).

In 20 patients, plasma concentrations measured before or 5 to 8 hours after the daily dose of 0.05 to $0.25 \mathrm{mg}$ and, therefore, regarded as representative of concentrations present throughout most of the day, ranged from 1.0 to $4.89 \mu \mathrm{g}$ per $100 \mathrm{ml}$. Concentration varied directly $(r=0.91)$ with the maintenance dose of digitoxin in micrograms per kilogram of body weight (Figure 4). Most subjects were receiving $0.1 \mathrm{mg}$ per day, and their plasma levels approximated $2 \mu \mathrm{g}$ per $100 \mathrm{ml}$.

Five patients who had previously taken priming doses of digitoxin experienced abrupt onset of anorexia and nausea after receiving 0.25 to $0.6 \mathrm{mg}$ ( 4.0 to $6.6 \mu \mathrm{g}$ per $\mathrm{kg}$ ) of the glycoside daily for 6 to 30 days. Their plasma digitoxin concentrations were 4.33 to $6.41 \mu \mathrm{g}$ per $100 \mathrm{ml}$. Two pa-

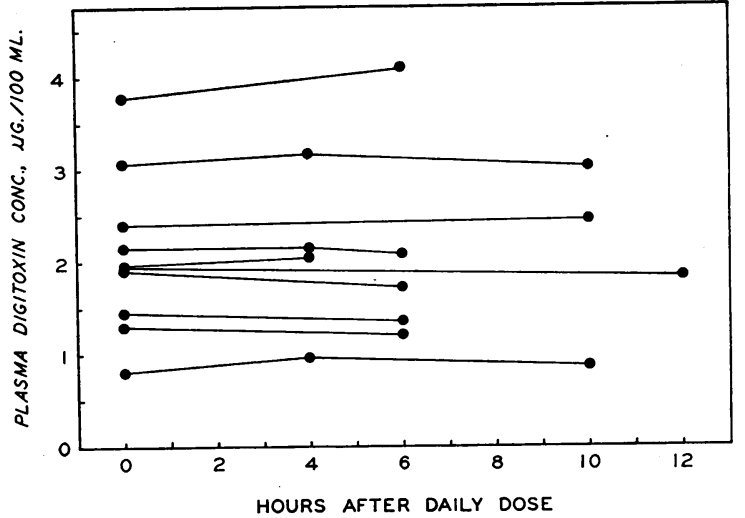

Fig. 3. Plasma digitoxin concentrations in 10 paTIENTS BEFORE AND 4 TO 12 HOURS AFTER DAILY DOSES OF 0.1 TO 0.25 MG WERE INGESTED.

tients vomited; one of them with a plasma concentration of $5.6 \mu \mathrm{g}$ per $100 \mathrm{ml}$ also experienced scotomas and blurring of vision.

The highest plasma concentration, $6.68 \mu \mathrm{g}$ per $100 \mathrm{ml}$, was encountered in a patient who developed atrial tachycardia with $2: 1$ atrioventricular block after $3.2 \mathrm{mg}$ digitoxin had been administered intramuscularly in 4 days (average daily dose, $6.7 \mu \mathrm{g}$ per $\mathrm{kg}$ ). The arrhythmia subsided within 4 days after the drug was withheld, and after 10 additional days, during which $0.1 \mathrm{mg}$ (1.79 $\mu \mathrm{g}$ per $\mathrm{kg}$ ) was taken daily by mouth, the plasma concentration had fallen to $1.62 \mu \mathrm{g}$ per $100 \mathrm{ml}$.

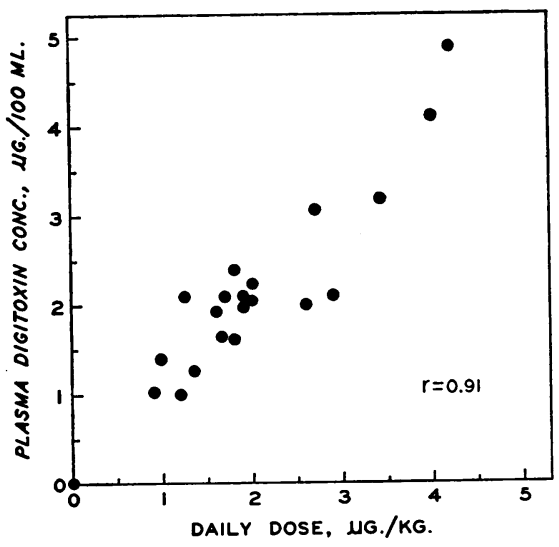

Fig. 4. RELATIONSHip OF PLASMa digitoxin CONCENTRATION TO DAILY DOSE OF DIGITOXIN IN 20 PATIENTS TREATED CHRONICALLY. The correlation coefficient is shown. Included in the plot, but not in the statistical computations, are values for three subjects to whom digitoxin was never administered. 
Another patient who developed atrial tachycardia with $2: 1$ atrioventricular block after 1 month on a daily dose of $0.3 \mathrm{mg}(6.9 \mu \mathrm{g}$ per $\mathrm{kg}$ ) had a plasma concentration of $2.85 \mu \mathrm{g}$ per $100 \mathrm{ml}$ 5 days after onset of the arrhythmia and discontinuation of the drug.

Persistence of digitoxin in the plasma after cessation of treatment was studied in two patients who had been maintained on $0.1 \mathrm{mg}$ per day. Plasma digitoxin concentration declined exponentially with time. In one patient, the half-time of digitoxin in the plasma was 4.3 days (Figure 5). In the other patient, who had slight impairment of renal function with a blood urea nitrogen of $25 \mathrm{mg}$ per $100 \mathrm{ml}$, the plasma half-time was 6.4 days.

To determine whether the red cells and other formed elements of the blood contribute to the circulating pool of digitoxin, the glycoside was measured in $25 \mathrm{ml}$ of blood and $15 \mathrm{ml}$ of plasma of single blood samples obtained from each of ten patients. The hematocrit of each blood sample was corrected for trapped plasma (67) and used to calculate the amount of digitoxin expected in whole blood on the basis of its plasma content.

Digitoxin concentration in plasma varied between 1.04 and $3.70 \mu \mathrm{g}$ per $100 \mathrm{ml}$, and in every patient exceeded that in whole blood (Table II). The quantities of digitoxin in $100 \mathrm{ml}$ whole blood were not significantly different $(p>0.5)$ from the amounts expected to be present in the contained plasma.

These results are supported by experiments in

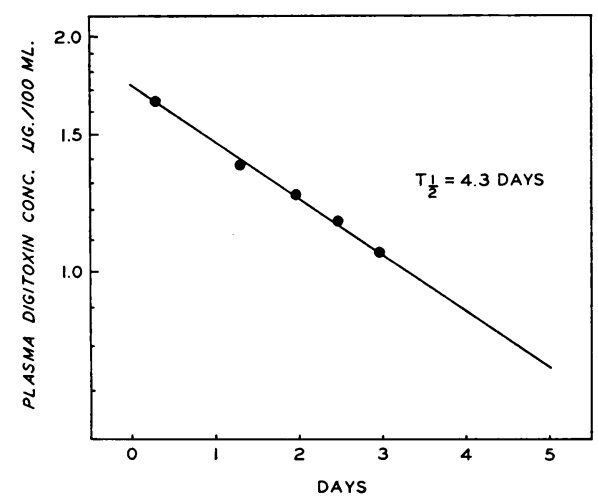

Fig. 5. Decrease of Plasma digitoxin concentraTION WITH TIME AFTER TREATMENT WAS DISCONTINUED IN A 63-YEAR-OLD MAN. The last daily dose of $0.1 \mathrm{mg}$ was administered at zero time. Concentration is presented on a logarithmic scale. The half-time is shown.
TABLE II

Concentration of digitoxin in plasma and whole blood of ten subjects treated with digitoxin

\begin{tabular}{cccc}
\hline & \multicolumn{3}{c}{ Digitoxin concentration } \\
\cline { 2 - 4 } & \multicolumn{3}{c}{ Blood } \\
\cline { 2 - 4 } Hematocrit & Plasma & Found & Expected* \\
\hline$\%$ & & $\mu g / 100 \mathrm{ml}$ \\
36.2 & 1.04 & 0.63 & 0.66 \\
37.5 & 1.08 & 0.67 & 0.68 \\
37.9 & 1.18 & 0.69 & 0.73 \\
37.2 & 1.19 & 0.80 & 0.75 \\
35.2 & 1.78 & 1.22 & 1.15 \\
40.4 & 1.84 & 1.11 & 1.10 \\
46.9 & 1.95 & 1.18 & 1.03 \\
44.7 & 2.73 & 1.36 & 1.51 \\
38.2 & 2.76 & 1.74 & 1.70 \\
39.6 & 3.70 & 2.29 & 2.24 \\
& & & \\
& Average & 1.17 & 1.15 \\
\end{tabular}

* Concentration expected if the cells contained no digitoxin.

which incubation of digitoxin- ${ }^{3} \mathrm{H}$ with blood at $37^{\circ} \mathrm{C}$ was followed by assay of tritium activity of dichloromethane extracts of the blood and its plasma. The concentration of digitoxin in the red cells was $2 \%$ of that in the plasma.

Excretion of digitoxin in urine. Eleven patients taking $0.1 \mathrm{mg}$ of the drug (1.3 to $2.6 \mu \mathrm{g}$ per $\mathrm{kg}$ ) daily excreted 8.3 to $30.3 \mu \mathrm{g}$ (average, $15.8 \mu \mathrm{g}$ ) in the urine during a 24-hour period. In nine of the subjects in whom plasma concentration was measured before and twice after the absorption peak, urinary excretion of the compound varied directly $(r=0.88)$ with its plasma concentration (Figure 6). One subject treated with 0.4 $\mathrm{mg}$ per day had a plasma concentration of $5.6 \mu \mathrm{g}$

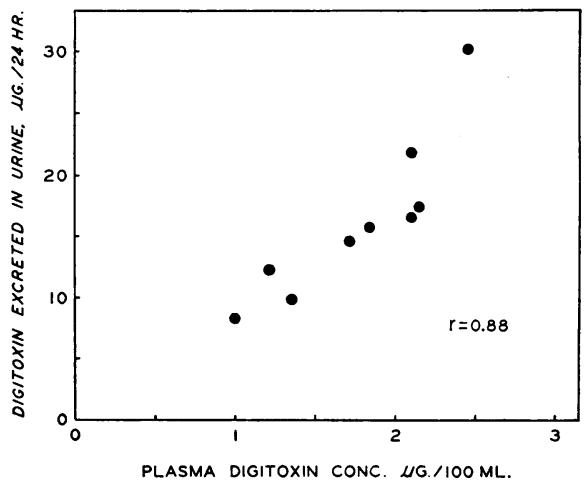

Fig. 6. RELATIONSHip OF RATE OF URINARY EXCRETION OF DIGITOXIN TO PLASMA DIGITOXIN CONCENTRATION IN NINE PATIENTS MAINTAINED ON A DAILY DOSE OF 0.1 MG. The correlation coefficient is indicated. 
per $100 \mathrm{ml}$ and excreted an average of $49 \mu \mathrm{g}$ in 24 hours. His data fall on the regression line defined by the points in Figure 6 .

One patient with cardiac failure easily controlled by $0.2 \mathrm{mg}(2.7 \mu \mathrm{g}$ per $\mathrm{kg})$ of digitoxin daily had slight impairment of renal function with a blood urea nitrogen concentration of $25 \mathrm{mg}$ per $100 \mathrm{ml}$. He excreted only $15.4 \mu \mathrm{g}$ of digitoxin in 24 hours despite a plasma level of $3.0 \mu \mathrm{g}$ per $100 \mathrm{ml}$. Another patient with marked chronic renal insufficiency required two periods of hemodialysis weekly for control of uremia and had been maintained on $0.1 \mathrm{mg}(2.0 \mu \mathrm{g}$ per $\mathrm{kg})$ of digitoxin daily for 10 months. His plasma concentration was $0.7 \mu \mathrm{g}$ per $100 \mathrm{ml}$, and his 24-hour urinary excretion of digitoxin was only $0.3 \mu \mathrm{g}$. The data from both subjects fall well below the points in Figure 6. Neither had manifested signs attributable to toxic effects of the glycoside.

The possibility that an additional quantity of digitoxin might be excreted as a conjugate of glucuronic acid was investigated in four patients. One hundred $\mathrm{ml}$ urine was incubated at $37^{\circ} \mathrm{C}$ for 24 hours with $100,000 \mathrm{U}$ bovine hepatic $\beta$-glucuronidase $^{10}$ at $\mathrm{pH} 4.8$ maintained by a sodium acetate-acetic acid buffer. A $100-\mathrm{ml}$ portion of urine from the same sample was incubated with buffer as a control. Digitoxin content was determined by the usual method except that the digitoxin- ${ }^{3} \mathrm{H}$ used to monitor procedural losses was added to the urine before incubation. The digitoxin content of samples treated with $\beta$-glucuronidase did not differ significantly from that of the control samples (Table III). Additional studies utilizing $\beta$-glucuronidase derived from Escherichia coli also failed to demonstrate digitoxin glucuronoside in the urine.

Excretion of digitoxin in stool. Five patients maintained on $0.1 \mathrm{mg}$ digitoxin excreted 9.3 to

TABLE III

Effect of $\beta$-glucuronidase on digitoxin content of $100 \mathrm{ml}$ urine

\begin{tabular}{ccc}
\hline & \multicolumn{2}{c}{ Digitoxin content } \\
\cline { 2 - 3 } Subject & Control & Treated \\
\hline & \multicolumn{3}{c}{$\mu g$} \\
MF & 0.61 & 0.62 \\
AR & 2.10 & 2.16 \\
HH & 2.21 & 2.19 \\
DR & 2.70 & 2.80 \\
\hline
\end{tabular}

10 Ketodase, Warner-Chilcott, Morris Plains, N. J.
TABLE IV

Plasma concentration and daily excretion of digitoxin in patients treated chronically

\begin{tabular}{|c|c|c|c|c|c|}
\hline \multirow[b]{2}{*}{ Patient } & \multirow{2}{*}{$\begin{array}{l}\text { Daily } \\
\text { dose }\end{array}$} & \multirow{2}{*}{$\begin{array}{l}\text { Plasma } \\
\text { concen- } \\
\text { tration }\end{array}$} & \multicolumn{3}{|c|}{ Excretion } \\
\hline & & & Urine & Stool & Total \\
\hline & $m g$ & $\mu \mathrm{g} / 100 \mathrm{ml}$ & $\mu g / d a y$ & $\mu g / d a y$ & $\mu g / d a y$ \\
\hline FB & 0.1 & 1.71 & 14.6 & 9.3 & 23.9 \\
\hline PL & 0.1 & 1.83 & 15.8 & 9.7 & 25.5 \\
\hline $\mathrm{AL}$ & 0.1 & 2.10 & 21.8 & 14.5 & 36.3 \\
\hline AR & 0.1 & 2.15 & 17.4 & 17.8 & 35.2 \\
\hline GP & 0.1 & 2.40 & 30.3 & 18.8 & 49.1 \\
\hline $\mathrm{MN}$ & 0.4 & 5.60 & 49.0 & 41.8 & 90.8 \\
\hline $\mathrm{GW}^{*}$ & 0.2 & 3.00 & 15.4 & 8.6 & 24.0 \\
\hline $\mathrm{JR} †$ & 0.1 & 0.70 & 0.3 & 4.4 & 4.7 \\
\hline
\end{tabular}

* Slight impairment of renal function.

$\dagger$ Marked chronic renal insufficiency.

$18.8 \mu \mathrm{g}$ (average, $14.0 \mu \mathrm{g}$ ) daily in the stool. The patient on a daily dose of $0.4 \mathrm{mg}$ excreted $41.8 \mu \mathrm{g}$ per day. The subject with slight disturbance of renal function excreted $8.6 \mu \mathrm{g}$ of his $0.2-\mathrm{mg}$ dose daily, and only $4.4 \mu \mathrm{g}$ per day appeared in the stool of the patient with advanced renal insufficiency.

Although the analytic blank for stool is relatively high, it could not have accounted for more than $0.1 \mu \mathrm{g}$ of the above values, since none of the 3-day stool collections exceeded $761 \mathrm{~g}$.

Fecal excretion of digitoxin closely paralleled urinary excretion of the glycoside in magnitude (Table IV). The total daily output of digitoxin in the urine and feces was 23.9 to $49.1 \mu \mathrm{g}$ (average, $34 \mu \mathrm{g}$ ) in patients taking $0.1 \mathrm{mg}$ per day. Total daily output of the patient on $0.4 \mathrm{mg}$ was $90.8 \mu \mathrm{g}$. Only $24 \mu \mathrm{g}$ of a daily dose of $0.2 \mathrm{mg}$ was excreted by the patient with mild renal disease, and only $4.7 \mu \mathrm{g}$ of a daily dose of $0.1 \mathrm{mg}$ appeared in the urine and stool of the subject with chronic renal failure.

\section{Discussion}

Few observations have been made on digitoxin in the plasma of man. When utilizing bioassay with the duck embryo heart, Friedman and coworkers were able to detect the glycoside in the serum for only 3 hours after it had been administered intravenously to four subjects $(33,34)$. Okita and associates administered 0.5 to $1.5 \mathrm{mg}$ ${ }^{14} \mathrm{C}$-labeled digitoxin intravenously to eight patients with cardiac failure, and during the ensuing 96 hours followed the decline of whole blood concentrations to levels as low as a "trace" to 0.1 $\mu \mathrm{g}$ per $100 \mathrm{ml}$ (45). No information exists on 
digitoxin in the blood of patients taking it by mouth or undergoing long-term treatment, although Friedman, St. George, and Bine reported that they could not detect the glycoside in the sera of such patients or of individuals who had ingested doses as large as $7 \mathrm{mg}$ (34).

Interest in patients maintained on the drug for a prolonged period was prompted by the consideration that in these patients the rate of dissipation of the drug is probably evenly balanced by the intake of the drug. Under these circumstances, the plasma concentration and rates of excretion were expected to be relatively free of effects related to distribution of the glycoside within the body and to a markedly fluctuating body pool of the compound. Without these complications, analysis of interrelationships among dose, excretion, and plasma levels might be simplified, and the plasma concentration may be regarded less equivocally as an index to tissue concentrations.

The data indicate that patients maintained on digitoxin by mouth have concentrations of digitoxin in their plasma of 1.0 to $5.6 \mu \mathrm{g}$ per $100 \mathrm{ml}$. These concentrations remain fairly constant during the course of the day except for an increase of 20 to $30 \%$ during the 4 to 6 hours after the daily dose is taken. Although the basic concentration varied widely, even among patients taking the same dose of $0.1 \mathrm{mg}$ in whom levels of 1.0 to 2.4 $\mu \mathrm{g}$ per $100 \mathrm{ml}$ were observed, it was directly and strongly dependent on the magnitude of the daily dose per unit of body weight. The regression equation derived from the data in Figure 4 reveals that each microgram of the dose per kilogram of body weight is capable of sustaining a plasma concentration of approximately $1 \mu \mathrm{g}$ per $100 \mathrm{ml}$.

Since all subjects received $1.2 \mathrm{mg}$ of the glycoside as a priming dose, and since no relationship could be demonstrated between this dose per unit of body 'weight and the plasma concentration established during long-term treatment, adjustments in plasma and tissue concentrations to levels consonant with daily intake undoubtedly occurred. Serial measurements of the body pool of the compound will be required to define the direction of these adjustments. The paramount role of the daily dose relative to body weight in regulating the concentration of digitoxin in the plasma and, presumably, in other tissues has distinct therapeutic implications.
The toxic manifestations of the cardioactive steroids are influenced by many factors that may modify the relationship between plasma and tissue concentrations of these agents and the development of adverse effects. The relationship may also be obscured by the presence of cardioactive metabolites of the parent compound. The present data, however, suggest that toxic effects of digitoxin may appear when the plasma concentration exceeds $4 \mu \mathrm{g}$ per $100 \mathrm{ml}$, and that they are very likely to occur at concentrations greater than $5 \mu \mathrm{g}$ per $100 \mathrm{ml}$. These concentrations are two or more times greater than those commonly present during daily maintenance on $0.1 \mathrm{mg}$.

The blood reservoir of digitoxin is not large and constitutes a small fraction of the total body pool (46). At a volume of $3 \mathrm{~L}$, the plasma of patients maintained on $0.1 \mathrm{mg}$ contains 30 to $70 \mu \mathrm{g}$ of the glycoside, but with larger doses as much as 170 $\mu \mathrm{g}$ may be present in the plasma. Since the concentration of digitoxin in blood cells is only $2 \%$ of the plasma value, the quantity carried in the cells represents a very minor fraction of the blood reservoir. It is very unlikely that complete replacement of the blood, as may occur under numerous circumstances, would seriously affect tissue concentrations or body pool of the glycoside. The loss would be equivalent to approximately half the daily dose.

Relative diurnal constancy of the plasma digitoxin concentration is a reflection of the long halftime of the steroid in the body. The present study tentatively defines the half-time in plasma as 4 to 6 days. Okita and co-workers calculated a whole blood half-time of 2 to $2 \frac{1}{4}$ days for intravenously administered digitoxin $-{ }^{14} \mathrm{C}$ (45). Okita later observed, however, that the half-time for urinary excretion of the ${ }^{14} \mathrm{C}$-labeled compound was 9 days (49); he attributed the disparity between the two values to failure to define the course of the blood concentration for a sufficient period of time. It is also possible that the solvent partition and alumina chromatography methods they used to separate digitoxin from its metabolic products did not succeed in separation of compounds closely related to the parent glycoside. In contrast to digitoxin, the more polar glycoside digoxin has a half-time of 31 hours in the blood $(52,53)$ and 1.8 days in the urine (68).

Of fundamental physiologic significance is the 
state of digitoxin in the plasma. Previous investigations $(69,70)$ have revealed an affinity of digitoxin for serum albumin. Studies in our laboratory utilizing equilibrium dialysis and other techniques have demonstrated that $97 \%$ of the digitoxin in human plasma is bound to protein, and that the binding is almost entirely attributable to an interaction of the glycoside with plasma albumin (71). Thus, within the range of digitoxin concentrations observed and at normal levels of plasma albumin, only $3 \%$ of plasma digitoxin exists in a freely diffusible unbound state. Only the free digitoxin is in direct equilibrium with the tissue stores of the steroid and available for filtration in the renal glomeruli. The tight association with albumin is one of the factors controlling the size of the plasma pool and the stability of digitoxin in the plasma.

The renal excretion of digitoxin varies directly with the plasma concentration of the compound. The relationship between the two variables is such that approximately $9 \mu \mathrm{g}$ of the glycoside is excreted daily for each $\mu \mathrm{g}$ per $100 \mathrm{ml}$ plasma. The average daily urinary excretion of $15.8 \mu \mathrm{g}$ is only $40 \%$ of the value reported by Friedman and associates $(35,36)$ for normal human subjects and patients with cardiac failure maintained on the same dose of digitoxin. Since these investigators bioassayed chloroform extracts of urine without preliminary isolation of the authentic glycoside, their measurements included all physiologically active metabolites of the steroid that the extract contained.

Renal clearance of digitoxin was not measured in the present study, but in the ten patients whose excretion and plasma concentrations were measured during the same day, the average renal clearance was equivalent to $0.6 \mathrm{ml}$ of plasma per minute. The small concentration of unbound digitoxin in the plasma partly accounts for this low rate. Also, unless glomerular filtration was markedly curtailed in these subjects, it is probable that the renal tubules reabsorbed significant quantities of the compound. Numerous aspects of the processes controlling excretion of digitoxin by the kidney, including the possibility of renal tubular secretion, remain to be elucidated.

Fecal excretion of digitoxin in patients maintained on $0.1 \mathrm{mg}$ averaged $14 \mu \mathrm{g}$ per day, or $70 \%$ of the simultaneously measured values for uri- nary excretion. Fecal excretion paralleled plasma concentration and urinary excretion in magnitude. In the patients with renal disease and impaired renal excretion of digitoxin, elimination of glycoside in the stools was also low.

Other measurements of fecal excretion of digitoxin in patients treated chronically with the glycoside have not been reported, but Okita and associates (46) found that $9 \%$ of an intravenous dose of 0.5 to $1.5 \mathrm{mg}$ of digitoxin $-{ }^{14} \mathrm{C}$ appeared in the stool during the subsequent 14 days. On the basis of analyses of digitoxin $-{ }^{14} \mathrm{C}$ in the gallbladder, jejunum, ileum, colon, and the intraluminal contents of these organs, these workers have postulated that digitoxin is secreted into the bile and subsequently is partly reabsorbed in the small intestine ("enterohepatic recycling") and partly eliminated in the stool.

In animals, all major segments of the gastrointestinal tract are capable of absorbing the drug $(34,41)$, and the rectal route is an effective mode of administering the compound in man (72). The present study has demonstrated fairly prompt, but not necessarily complete, absorption of digitoxin. The mechanism whereby some of the digitoxin excreted in the bile and possibly some of the ingested compound escape subsequent absorption is not clear. This problem, as well as the possibilities of intestinal secretion $(41,43,46)$ and intraintestinal degradation of the compound, requires clarification.

The data on urinary and fecal excretion indicate that patients maintained on $0.1 \mathrm{mg}$ daily excrete only 24 to $49 \%$ of the glycoside in unchanged form. Since excretion via other routes is probably negligible, it appears that the remaining 51 to $76 \mu \mathrm{g}$ of the compound was chemically altered before it was eliminated. In the two patients with renal disease who had been treated with the drug for months and manifested no evidence of toxicity, 95 and $176 \mu \mathrm{g}$ of the compound appeared to be metabolized daily. Because of the limited concentration of ultrafilterable digitoxin in the plasma, it is doubtful that hemodialysis, which was performed twice a week on one of the patients, removed much of his body store of the steroid. The concentration of digitoxin in his dialysis fluid after his blood was equilibrated in vivo with a bath of small volume was only $0.5 \mu \mathrm{g}$ per $\mathrm{L}$. The patient on a daily dose of $0.4 \mathrm{mg}$ appeared to metabo- 
lize $310 \mu \mathrm{g}$ per day. This dosage may have been at the upper limit of his capacity to excrete and inactivate the compound, since he manifested toxic reactions to the drug 1 month after he was studied.

Several schemata for the metabolism of digitoxin have been proposed. This investigation has demonstrated that simple conjugation with glucuronic acid and subsequent renal excretion of the polar glucuronoside is not a significant metabolic pathway for digitoxin. There is evidence that conversion of digitoxin to digoxin by $12 \beta$-hydroxylation occurs in man $(41,42,64)$ and in the rat $(41,42,60,61)$. Stepwise hydrolysis of the trisaccharide moiety of either glycoside to the didigitoxoside $(60,64)$, monodigitoxoside $(60)$, and genin $(60,61)$ has been demonstrated. In the liver, either of the genins may undergo epimerization to the physiologically inactive $3 \alpha$-hydroxy form, which is then conjugated with glucuronic or sulfuric acid $(61,63)$. The quantitative significance of these reactions has not been defined.

We have used the double isotope dilution derivative method to measure digoxin and digitoxigenin; preliminary studies indicate that it can also be modified to assay the other digitoxosides of both genins. These modified methods may aid in elucidating the metabolism of digitoxin in man.

\section{Summary}

A double isotope dilution derivative method was devised for measuring digitoxin in plasma, whole blood, urine, and stool. The method utilizes digitoxin ${ }^{3} \mathrm{H}$ to monitor procedural losses of digitoxin and acetic anhydride- $1-{ }^{14} \mathrm{C}$ to convert the compound to digitoxin triacetate- $1-{ }^{14} \mathrm{C}$. It is capable of detecting $0.01 \mu \mathrm{g}$ of the glycoside, and has an accuracy of $101 \pm 3 \%$ (mean $\pm \mathrm{SE}$ ) in assaying 0.01 to $0.2 \mu \mathrm{g}$ of the compound in plasma. The coefficient of variation of the method is $4 \%$ when $0.2 \mu \mathrm{g}$ in $10 \mathrm{ml}$ of plasma is measured.

The plasma of patients with cardiac disease who were treated chronically with fixed daily quantities of digitoxin contained 1.0 to $5.6 \mu \mathrm{g}$ of digitoxin per $100 \mathrm{ml}$. The concentration remained constant throughout the day except for an increase that began $\frac{1}{2}$ to 1 hour after the daily dose was ingested, attained at 1 hour a peak 17 to $30 \%$ greater than the initial level, and persisted for 4 and occasionally 6 hours. Plasma concentration varied directly with the size of the daily dose relative to body weight; each microgram taken daily per kilogram of weight sustained a concentration of approximately $1 \mu \mathrm{g}$ per $100 \mathrm{ml}$. The concentration of digitoxin in blood cells was only $2 \%$ of that in plasma. After cessation of treatment, the halftime for digitoxin in plasma was 4.3 days in one patient and 6.4 days in another patient with slight impairment of renal function. Patients manifesting toxic effects after large doses of the drug had plasma concentrations of 4.3 to $6.7 \mu \mathrm{g}$ per 100 $\mathrm{ml}$, levels more than twice those in patients taking $0.1 \mathrm{mg}$ daily.

Patients taking $0.1 \mathrm{mg}$ of the drug per day excreted 8 to $30 \mu \mathrm{g}$ (average, 15.8) in the urine and 9 to $19 \mu \mathrm{g}$ (average, 14) in the feces during 24 hours. The quantity excreted in the urine varied directly with plasma concentration; approximately $9 \mu \mathrm{g}$ was excreted daily for each microgram per $100 \mathrm{ml}$ of plasma. Fifty-one to $76 \mu \mathrm{g}$ (average, 66) of the daily intake of digitoxin was not recovered in the urine and stool, and probably was altered chemically before dissipation from the body. Two patients with impaired renal function excreted smaller fractions of their daily doses in both urine and feces and appeared to metabolize larger quantities of the drug. A patient maintained on $0.4 \mathrm{mg}$ per day excreted only $91 \mu \mathrm{g}$ of the glycoside daily.

Since glucuronosides of digitoxin susceptible to cleavage by $\beta$-glucuronidase could not be identified in the urine of patients treated with the glycoside, conjugation of digitoxin with glucuronic acid is not a significant metabolic process in man.

\section{Acknowledgments}

We wish to thank Drs. Robert I. Hamby, Stephen J. Gulotta, Costas T. Lambrew, and Jules R. Schwaber for their assistance during various phases of this study. The skilled technical assistance of Josefa Cubina is gratefully acknowledged.

\section{References}

1. Withering, W. An Account of the Foxglove and Some of its Medical Uses: With Practical Remarks on Dropsy and other Diseases. London, C. G. J. and J. Robinson, 1785. 
2. Raymond, W. D. Detection and estimation of ouabain and strophanthin. Analyst 1938, 63, 478.

3. Raymond, W. D. The m-dinitrobenzene reaction of ouabain and its application to the examination of East African arrow poison. Analyst 1939, 64, 113.

4. Kedde, D. L. The chemical investigation of digitalis preparations. Pharm. Weekbl. 1947, 82, 741.

5. Pratt, E. L. Colorimetric method for estimation of digitoxin. Analyt. Chem. 1952, 24, 1324.

6. Knudson, A., and M. Dresbach. A proposed method of chemically assaying active principles of the digitalis group (abstract). J. Pharmacol. exp. Ther. 1922, 19, 268.

7. Bell, F. K., and J. C. Krantz, Jr. A chemical evaluation of digitalis. J. Pharmacol. exp. Ther. 1945, 83, 213.

8. The Pharmacopeia of the United States of America, 16th ed. Washington, D. C., Board of Trustees, U. S. Pharmacopoeial Convention, 1960, p. 224.

9. Tattje, D. H. E. Colorimetric estimation of digitalis glycosides with 2:4-dinitrophenylsulphone. J. Pharm. Pharmacol. 1958, 10, 493.

10. Warren, A. T., F. O. Howland, and L. W. Green. Colorimetric assay of digitoxin. J. Amer. pharm. Ass., sci. Ed. 1948, 37, 186.

11. Canbäck, T. The chemical estimation of Digitalis and Strophantus glycosides. J. Pharm. Pharmacol. 1949, 1, 201.

12. Overend, W. G., and M. Stacey. The chemistry of the 2-desoxysugars. Advanc. Carbohyd. Chem. 1953, 8, 45.

13. Langejan, $H$. Reactions of some cardiac glycosides useful for evaluation of digitalis leaves. Pharm. Weekbl. 1951, 86, 593.

14. Von Euw, J., and T. Reichstein. The glycosides of the seeds of Strophantus nicholsonii. Helv. chim. Acta 1948, 31, 883.

15. Arreguine, V., and P. E. Pasqualis. Xanthydrol in acetic-hydrochloric acid medium as reagent for digitoxin. Revista de la Universidad Nacional de Córdoba (Argentina) 1945, 32, 439.

16. Pesez, M. Le xanthydrol, réactif des désoses. Ann. pharm. franç. 1952, 10, 104.

17. Repke, K. Die chemische Bestimmung von Digitoxin in Geweben und Ausscheidungen. NaunynSchmiedeberg's Arch. exp. Path. Pharmak. 1958, 233, 261.

18. Webb, J. M., and H. B. Levy. A sensitive method for the determination of deoxyribonucleic acid in tissues and microorganisms. J. biol. Chem. 1955, 213, 107.

19. Tantivatana, P., and S. E. Wright. Estimation of digoxin and digitoxin in Digitalis lanata. J. Pharm. Pharmacol. 1958, 10, 189.

20. Reichstein, T., and E. Weiss. The sugars of the cardiac glycosides. Advanc. Carbohyd. Chem. 1962, 17,65 .
21. Paist, W. D., E. R. Blout, F. C. Uhle, and R. C. Elderfield. Studies on lactones related to the cardiac aglucons. III. The properties of $\beta$-substituted $\Delta \alpha, \beta$-butenolides, and suggested revision of the structure of the side chain of the Digitalis-Strophantus aglucons. J. org. Chem. 1941, 6, 273.

22. Petit, A., M. Pesez, P. Bellet, and G. Amiard. Pure digitoxin. Bull. Soc. chim. Fr. 1950, 17, 288.

23. Jensen, K. B. Paper-chromatographic separation and fluorimetric determination of gitoxigenin, gitoxin, and purpureaglycoside B. Acta pharmacol. (Kbh.) $1952,8,110$.

24. Jensen, K. B. Fluorimetric determination of gitoxigenin. Acta Pharmacol. (Kbh.) 1953, 8, 101.

25. Jensen, K. B. Chemical and biological assay of Digitalis purpurea. Acta pharmacol. (Kbh.) 1957, 13, 381.

26. Silberman, H., and R. H. Thorp. The estimation of the component cardiac glycosides in digitalis plant samples using paper chromatography and fluorescence photography. J. Pharm. Pharmacol. 1953, 5, 438.

27. Jakovljevic, I. M. New fluorometric micromethod for the simultaneous determination of digitoxin and digoxin. Analyt. Chem. 1963, 35, 1513.

28. Friedman, M., and R. Bine, Jr. Employment of the embryonic duck heart for the detection of minute amounts of a digitalis glycoside (lanatoside $\mathrm{C}$ ). Proc. Soc. exp. Biol. (N. Y.) 1947, 64, 162.

29. Friedman, M., S. O. Byers, R. Bine, Jr., and C. Bland. Renal excretion of digitoxin in man following oral administration. Proc. Soc. exp. Biol. (N. Y.) 1949, 72, 468.

30. St. George, S., C. F. Naegele, F. S. French, R. H. Rosenman, and M. Friedman. A quantitative study of the digitoxin content of edema fluids. J. clin. Invest. 1953, 32, 1222.

31. St. George, S., R. Bine, Jr., and M. Friedman. Role of the liver in excretion and destruction of digitoxin. Circulation 1952, 6, 661 .

32. St. George, S., and M. Friedman. The intestinal excretion of digitoxin in the rat. Circulation 1952, $6,851$.

33. Friedman, M., S. O. Byers, and R. Bine, Jr. Rate of disappearance of digitoxin from the blood of man after its parenteral administration. Fed. Proc. 1951, 10, 46.

34. Friedman, M., S. St. George, and R. Bine, Jr. The behavior and fate of digitoxin in the experimental animal and man. Medicine (Baltimore) 1954, 33, 15.

35. Friedman, M., R. Bine, Jr., S. O. Byers, and C. Bland. The renal excretion of digitoxin in the normal subject after single and continuous administration of the drug. Circulation 1950, 2, 749.

36. Friedman, M., S. St. George, R. Bine, Jr., and S. O. Byers. The renal excretion of digitoxin in the acute and chronic cardiac patient. Circulation 1952, 6, 853. 
37. Friedman, M., S. St. George, R. Bine, Jr., S. O. Byers, and C. Bland. Deposition and disappearance of digitoxin from the tissues of the rat, rabbit, and dog after parenteral injection. Circulation 1952, 6, 367.

38. Friedman, M., and R. Bine, Jr. A study of the rate of disappearance of a digitalis glycoside (lanatoside C.) from the blood of man. J. clin. Invest. 1949, 28, 32.

39. Shepheard, E. E., R. H. Thorp, and S. E. Wright. The excretory products of digoxin in the rat. J. Pharmacol. exp. Ther. 1954, 112, 133.

40. Brown, B. T., D. Ranger, and S. E. Wright. The excretory products of lanatoside $\mathrm{C}$ and digitoxin in the rat. J. Pharmacol. exp. Ther. 1955, 113, 353.

41. Wright, S. E. The Metabolism of Cardiac Glycosides. A Review of the Absorption, Metabolism and Excretion of Clinically Important Cardiac Glycosides. Springfield, Ill., Charles C Thomas, 1960.

42. Ashley, J. J., B. T. Brown, G. T. Okita, and S. E. Wright. The metabolites of cardiac glycosides in human urine. J. biol. Chem. 1958, 232, 315.

43. Okita, G. T., F. E. Kelsey, P. J. Talso, L. B. Smith, and E. M. K. Geiling. Studies of the renal excretion of radioactive digitoxin in human subjects with cardiac failure. Circulation 1953, 7, 161.

44. Fischer, C. S., A. Sjoerdsma, and R. Johnson. The tissue distribution and excretion of radioactive digitoxin: studies on normal rats and cats, and rats with dietary-induced myocardial lesions. Circulation 1952, 5, 496.

45. Okita, G. T., P. J. Talso, J. H. Curry, Jr., F. D. Smith, Jr., and E. M. K. Geiling. Blood level studies of $\mathrm{C}^{\mathbf{1 4}}$-digitoxin in human subjects with cardiac failure. J. Pharmacol. exp. Ther. 1955, $113,376$.

46. G. T. Okita, P. J. Talso, J. H. Curry, Jr., F. D. Smith, Jr., and E. M. K. Geiling. Metabolic fate of radioactive digitoxin in human subjects. J. Pharmacol. exp. Ther. 1955, 115, 371.

47. Spratt, J. L., and G. T. Okita. Subcellular localization of radioactive digitoxin. J. Pharmacol. exp. Ther. 1958, 124, 115.

48. Sjoerdsma, A., and C. S. Fischer. The fixation of radioactive digitoxin by isolated hearts. Circulation 1951, 4, 100.

49. Okita, G. T. Studies with radioactive digitalis. J. Amer. Geriat. Soc. 1957, 5, 163.

50. Geiling, E. M. K., F. E. Kelsey, B. J. McIntosh, and A. Ganz. Biosynthesis of radioactive drugs using carbon 14. Sicience 1948, 108, 558.

51. Gonzalez, L. F., and E. C. Layne. Studies of tritiumlabeled digoxin: tissue, blood and urine determinations. J. clin. Invest. 1960, 39, 1578.

52. Doherty, J. E., W. H. Perkins, and G. K. Mitchell. Tritiated digoxin studies on human subjects. Arch. intern. Med. 1961, 108, 531.
53. Doherty, J. E., and W. H. Perkins. Studies with tritiated digoxin after intramuscular administration (abstract). Clin. Res. 1964, 12, 27.

54. Kliman, B., and R. E. Peterson. Double isotope derivative assay of aldosterone in biological extracts. J. biol. Chem. 1960, 235, 1639.

55. Peterson, R. E. Use of radioisotopes in steroid methodology in Lipids and the Steroid Hormones in Clinical Medicine, F. W. Sunderman, and F. W. Sunderman, Jr., Eds. Philadelphia, J. B. Lippincott, 1960, p. 141.

56. Peterson, R. E. Determination of peripheral plasma aldosterone in Aldosterone. A Symposium Organized by the Council for International Organizations of Medical Sciences Established under Joint Auspices of UNESCO \& WHO, E. E. Baulieu and P. Robel, Eds. Philadelphia, Davis, 1964, p. 145.

57. Yankopoulus, N. A., J. O. Davis, B. Kliman, and R. E. Peterson. Evidence that a humoral agent stimulates the adrenal cortex to secrete aldosterone in experimental secondary hyperaldosteronism. J. clin. Invest. 1959, 38, 1278.

58. Wilzbach, K. E. Tritium-labeling by exposure of organic compounds to tritium gas. J. Amer. chem. Soc. 1957, 79, 1013.

59. Peterson, R. E., and E. A. Eilers. The use of labeled acetic anhydride in steroid assays. Part II of Excerpta Medica International Congress Series No. 83. Amsterdam, Excerpta Medica Foundation, Proceedings of the Second International Congress on Endocrinology, 1965, p. 267.

60. Repke, K. Die Bis- und Mono-digitoxoside des Digitoxigenins und Digoxigenins: Metaboliten des Digitoxins. Naunyn-Schmiedeberg's Arch. exp. Path. Pharmak. 1959, 237, 155.

61. Repke, K. Metabolism of cardiac glycosides in New Aspects of Cardiac Glycosides, W. Wilbrandt and P. Lindgren, Eds. New York, Macmillan, 1963, p. 47.

62. Repke, K., and L. T. Samuels. Evidence favoring the nonspecificity of 3-hydroxysteroid dehydrogenases in relation to steroid conformation. Biochemistry 1964, 3, 685.

63. Repke, K., and L. T. Samuels. Enzymatic basis for epimerization of cardiotonic steroids at carbon 3 in rat liver. Biochemistry 1964, 3, 689.

64. Wright, S. E. The identification of digoxin metabolite B (digitoxin metabolite C) with digoxigenin di-digitoxoside. J. Pharm. Pharmacol. 1962, 14, 613.

65. Snedecor, G. W. Statistical Methods Applied to Experiments in Agriculture and Biology, 5th ed. Ames, Iowa, Iowa State College Press, 1956.

66. Mandel, J. The Statistical Analysis of Experimental Data. New York, John Wiley \& Sons, 1964.

67. Chaplin, H., Jr., and P. L. Mollison. Correction for plasma trapped in the red cell column of the hematocrit. Blood 1952, 7, 1227. 
68. Marcus, F. I., G. J. Kapadia, and G. G. Kapadia. The metabolism of digoxin in normal subjects. J. Pharmacol. exp. Ther. 1964, 145, 203.

69. Fawaz, G., and A. Farah. A study of the digitoxin binding power of serum and other soluble tissueproteins of the rabbit. J. Pharmacol. exp. Ther. 1944, 80, 193.

70. Farah, A. On the combination of some cardio-active glycosides with serum proteins. J. Pharmacol. exp. Ther. 1945, 83, 143.
71. Lukas, D. S. Tissue concentration and protein-binding of digitalis. Symposium: Mechanisms of Action of Digitalis and Quinidine. Program of the Thirty-eighth Scientific Sessions of the American Heart Association, Miami Beach, Fla., Oct. 16, 1965.

72. Moe, G. K., and A. E. Farah. Digitalis and allied cardiac glycosides in The Pharmacological Basis of Therapeutics, 3rd ed., L. S. Goodman and A. Gilman, Eds. New York, Macmillan, 1965, p. 665. 